\title{
HUBUNGAN BEBERAPA FAKTOR RISIKO PENYAKIT JANTUNG KORONER DENGAN LAJU FILTRASI GLOMERULUS PADA PASIEN INFARK MIOKARD LAMA
}

\author{
${ }^{1}$ Yanti Manoy
${ }^{2}$ Starry H. Rampengan
${ }^{2}$ Stella Palar
}

\author{
${ }^{1)}$ Mahasiswa Fakultas Kedokteran Universitas Sam Ratulangi Manado \\ ${ }^{2)}$ Dosen Bagian Ilmu Penyakit Dalam Universitas Sam Ratulangi Manado \\ Email: yantimanoy@yahoo.com
}

\begin{abstract}
Myocardial Infarction (MI) is one of the major causes of morbidity and mortality worldwide. The great number of coronary heart disease (CHD) risk factors can accelerate the process of atherosclerosis and the occurrence of MI where it is affects the Glomerular Filtration Rate (GFR). While some studies have showed that there is a link between CHD risk factors and GFR on the Acute Coronary Syndrome (ACS) patients, the data that supports this hypothesis is still rarely reported on the Old Myocardial Infarction (OMI) patients. Objective: To determine the correlation between several risk factors of CHD with GFR in OMI patients. Methods: This is a descriptive study with cross sectional analytic use the data of medical records at the heart of poly Hospital prof. Dr. R. D. Kandou Manado. Results: There were 205 patients from a total of 330 patients OMI period January 2013 - December 2013 is included as a sample in this study. The results showed that patients aged 6069 OMI most with 77 people (38 \%) with decreased GFR $(p<0.001)$. Patients with a history of hypertension, there are 148 people $(72 \%)$ with decreased GFR $(p<0,005)$. Patients with increased LDL there are 166 people $(80.9 \%)$ with decreased GFR $(p=0.088)$. Patients who have a history of diabetes, there are 50 men $(24.4 \%)$ with decreased GFR $(p=0.333)$. Patients with a history of smoking are 41 people $(20 \%)$ with decreased GFR $(p=0.103)$. Conclusion: There is a significant relationship between age and history of hypertension in patients OMI with GFR. There was no significant relationship between hyperlipidemia, diabetes mellitus and a history of smoking history in patients OMI with GFR.
\end{abstract}

Keywords: Risk factors of Coronary Heart Disease, Glomerular Filtration Rate, Old Myocardial Infarction.

\footnotetext{
Abstrak: Infark miokard (IM) merupakan salah satu penyebab utama kesakitan dan kematian di seluruh dunia. Banyaknya faktor risiko Penyakit Jantung Koroner (PJK) dapat mempercepat proses aterosklerosis dan terjadinya IM dimana hal ini juga berdampak pada Laju Filtrasi Glomerulus (LFG). Beberapa penelitian menunjukan adanya hubungan antara beberapa faktor risiko PJK dengan LFG pada pasien Sindrom Koroner Akut (SKA), tetapi data tentang hubungan tersebut pada pasien Infark Miokard Lama (OMI) masih jarang dilaporkan. Tujuan: Untuk mengetahui hubungan beberapa faktor risiko PJK dengan LFG pada pasien OMI. Metode: Penelitian ini bersifat deskriptif analitik cross sectional terhadap pasien OMI dengan menggunakan data rekam medik di poli jantung RSUP Prof. Dr. R. D. Kandou Manado. Hasil: Terdapat 205 pasien dari total 330 pasien OMI periode Januari 2013-Desember 2013 yang masuk sebagai sampel penelitian ini. Hasil penelitian menunjukan bahwa pasien OMI paling banyak berusia 60-69 dengan 77 orang (38\%) memiliki LFG menurun $(p<0,001)$. Pasien dengan riwayat hipertensi sebanyak 148 orang $(72 \%)$ dengan LFG menurun $(p<0,005)$. Pasien dengan LDL meningkat ditemukan pada 166 orang $(80,9 \%)$ dengan LFG menurun $(p=0,088)$. Pasien yang mempunyai riwayat DM terdapat pada 50 orang $(24,4 \%)$ dengan LFG menurun $(p=0,333)$. Pasien dengan riwayat merokok terdapat pada 41 orang (20\%) dengan LFG
} 
menurun $(p=0,103)$. Simpulan: Terdapat hubungan yang signifikan antara usia dan riwayat hipertensi dengan LFG pada pasien OMI. Tidak terdapat hubungan yang bermakna antara hiperlipidemia, riwayat DM dan riwayat merokok dengan LFG pada pasien OMI.

Kata Kunci: Faktor Risiko Penyakit Jantung Koroner, Laju Filtrasi Glomerulus, Infark Miokard Lama.

Penyakit Jantung Koroner (PJK) merupakan kondisi yang terjadi akibat penumpukan plak di arteri jantung sehingga mengakibatkan suplai darah ke jantung menjadi terganggu dan bisa menyebabkan serangan jantung. ${ }^{1}$ Beberapa jenis penyakit yang termasuk dalam PJK sendiri antara lain angina pektoris, infark miokard akut/acute myocardial infarction (AMI), infark miokard lama/old myocardial infarction (OMI), gagal jantung. ${ }^{2}$

Penyakit jantung koroner adalah penyebab utama kematian di seluruh dunia, dan 3,8 juta pria serta 3,4 juta perempuan meninggal akibat penyakit tersebut setiap tahun. Penyakit Jantung Koroner merupakan penyebab 48\% kematian akibat penyakit kardiovaskuler pada tahun 1998 di Amerika Serikat. $^{3}$

Hasil dari Jakarta cardiovascular study pada tahun 2008 mencatat prevalensi infark miokard lama pada wanita mencapai 4,12\% dan 7,6\% pada pria, atau 5,29 secara keseluruhan. Angka ini jauh di atas prevalensi infark miokard pada tahun 2000, yakni hanya $1,2 \%$ saja. Hal ini mendukung hasil survei Departemen Kesehatan Rakyat Indonesia yang menunjukkan bahwa prevalensi infark miokard lama di Indonesia semakin meningkat dari tahun ke tahun. ${ }^{4}$

Tingginya tingkat prevalensi pada infark miokard membuat peneliti melakukan, banyak penelitian-penelitian untuk menurunkan insiden, salah satunya mengenai faktor-faktor risiko penyakit ini. Faktor risiko infark miokard terbagi 2 , faktor risiko yang tidak dapat diubah, seperti usia, jenis kelamin, ras, dan riwayat keluarga; dan faktor resiko yang dapat diubah, seperti peningkatan kadar kolesterol total, kolesterol LDL, trigliserida, hipertensi, merokok, gangguan toleransi glukosa dan lain-lain. ${ }^{5}$

Pada keadaan patologis seperti adanya lesi aterosklerosis, maka serotonin, ADP dan asetilkolin justru merangsang pelepasan Endothelial derived constricting factor (EDCP) yang menyebabkan kontriksi pembuluh darah, termasuk arteriol ginjal. Pembuluh darah ginjal, baik arteriol aferen maupun eferen dipersyarafi oleh serabut saraf simpatis. ${ }^{6}$

Aktivitas saraf simpatis ginjal yang kuat dapat mengakibatkan konstriksi arteriol ginjal. Kontriksi arteriol eferen akan menyebabkan penurunan aliran darah ke ginjal. Karena itu jika konstriksi arteriol cukup berat, maka kenaikan tekanan osmotik koloid akan melebihi tekanan hidrostatik kapiler glomerulus yang disebabkan oleh konstriksi arteriol eferen. Bila hal ini terjadi, daya akhir filtrasi menjadi turun yang pada akhirnya juga akan menyebabkan penurunan laju filtrasi glomerulus (LFG). Laju aliran darah yang lebih rendah kedalam glomerulus akan menyebabkan penurunan LFG.

\section{METODE PENELITIAN}

Data penelitian diambil dari bulan Oktober 2013 - Desember 2013. Penelitian yang dilakukan bersifat deskriptif analitik cross sectional dengan menggunakan data sekunder sebagai acuan. Tempat penelitia di poli jantung RSUP Prof. Dr. R. D. Kandou Manado. Populasi dari penelitian ini adalah seluruh pasien Infark miokard lama/Old myocardial infarction (OMI). Sampel penelitian ini adalah pasien OMI dengan beberapa faktor risiko PJK. Sampel penelitian diambil dengan memenuhi kriteria inklusi diantaranya: Pasien OMI dengan identitas lengkap, ada riwayat Hipertensi/Hipertensi terkontrol, ada riwayat Diabetes Melitus (DM)/DM terkontrol, ada riwayat merokok, dan data lab kreatinin serum dan kadar kolestrol Low Density Lipoprotein (LDL). 
Pengumpulan data dilakukan dengan melihat data lengkap pasien OMI di poli jantung RSUP Prof. Dr. R. D. Kandou Manado periode Oktober-Desember 2013. Pengolahan data dilakukan menggunakan kalkulator dan program komputer SPSS versi 20. Data yang ada dihitung dalam bentuk distribusi frekuensi.

\section{HASIL}

Pada penelitian ini didapatkan jumlah pasien OMI yang berkunjung di poliklinik jantung periode Januari-Desember 2013 adalah sebanyak 330 orang dan yang termasuk kriteria inklusi pada penelitian ini adalah 205 orang.

Dari hasil penelitian menunjukan bahwa terdapat 2 orang (1\%) dengan usia 30-39 tahun memiliki LFG normal dan tidak terdapat pasien (0\%) dengan LFG menurun, pada pasien dengan usia 40-49 tahun terdapat 2 orang (1\%) dengan LFG normal dan terdapat 7 orang (3\%) dengan LFG menurun, pada pasien dengan usia 50-59 tahun terdapat 6 orang (3\%) dengan LFG normal dan terdapat 50 orang (24\%) dengan LFG menurun, pada pasien dengan usia 6069 tahun terdapat 2 orang (1\%) dengan LFG normal dan terdapat 77 orang (38\%) dengan LFG menurun, pada pasien dengan usia 70-79 tahun tidak terdapat pasien $(0 \%)$ dengan LFG normal dan terdapat 51 orang (25\%) dengan LFG menurun, pada pasien dengan usia 80-89 tahun tidak terdapat pasien (0\%) dengan LFG normal dan terdapat 8 orang (4\%) dengan LFG menurun.

Tabel 1. Distribusi berdasarkan Umur dan LFG

\begin{tabular}{|c|c|c|c|c|c|}
\hline \multirow[t]{2}{*}{ Umur } & \multicolumn{2}{|c|}{$\begin{array}{c}\text { LFG } \\
\text { Normal }\end{array}$} & \multicolumn{2}{|c|}{$\begin{array}{c}\text { LFG } \\
\text { Menurun }\end{array}$} & \multirow[t]{2}{*}{$P$} \\
\hline & $\mathrm{n}$ & $\%$ & $\mathbf{n}$ & $\%$ & \\
\hline $30-39$ & 2 & 1 & 0 & 0 & \\
\hline $40-49$ & 2 & 1 & 7 & 3 & \\
\hline $50-59$ & 6 & 3 & 50 & 24 & 0,000 \\
\hline $60-69$ & 2 & 1 & 77 & 38 & $(p<0,05)$ \\
\hline $70-79$ & 0 & 0 & 51 & 25 & \\
\hline 80-89 & 0 & 0 & 8 & 4 & \\
\hline Total & 12 & 6 & 193 & 94 & \\
\hline
\end{tabular}

Nilai $p=0,000$ berarti dalam penelitian ini terdapat hubungan yang signifikan antara variabel umur dengan LFG (Tabel 1).

Dari hasil penelitian menunjukan bahwa terdapat 6 orang (3\%) dengan tidak ada hipertensi memiliki LFG normal dan terdapat 45 orang (22\%) memiliki LFG menurun, sedangkan pada pasien dengan hipertensi terdapat 6 orang (3\%) dengan LFG normal dan terdapat 148 orang (72\%) dengan LFG menurun. Nilai $p=0,048$ berarti dalam penelitian ini terdapat hubungan yang signifikan antara variabel tekanan darah dengan LFG.

Tabel 2. Distribusi Hipertensi dan LFG

\begin{tabular}{|c|c|c|c|c|c|}
\hline \multirow{2}{*}{$\begin{array}{l}\text { Riwayat } \\
\text { Hipertensi }\end{array}$} & \multicolumn{2}{|c|}{$\begin{array}{c}\text { LFG } \\
\text { Normal }\end{array}$} & \multicolumn{2}{|c|}{$\begin{array}{c}\text { LFG } \\
\text { Menurun }\end{array}$} & \multirow[t]{2}{*}{$\boldsymbol{P}$} \\
\hline & $\mathbf{n}$ & $\%$ & $n$ & $\%$ & \\
\hline $\begin{array}{c}\text { Tidak } \\
\text { Hipertensi }\end{array}$ & 6 & 3 & 45 & 22 & \multirow[t]{3}{*}{$\begin{array}{c}0,048 \\
(p<0,05)\end{array}$} \\
\hline Hipertensi & 6 & 3 & 148 & 72 & \\
\hline Total & 12 & 6 & 193 & 94 & \\
\hline
\end{tabular}

Dari hasil penelitian menunjukan bahwa terdapat 4 orang (2\%) dengan LDL normal memiliki LFG normal dan terdapat 27 orang (13,1\%) memiliki LFG menurun, sedangkan pada pasien dengan LDL meningkat terdapat 8 orang (4\%) dengan LFG normal dan terdapat 166 orang (80,9\%) dengan LFG menurun. Nilai $p=0,088$ berarti dalam penelitian ini tidak bisa dibuktikan adanya hubungan yang signifikan antara variabel LDL dengan LFG. (Tabel 3).

Tabel 3. Distribusi berdasarkan LDL dan LFG

\begin{tabular}{cccccc}
\hline \multirow{2}{*}{ LDL } & \multicolumn{2}{c}{ LFG } & \multicolumn{2}{c}{$\begin{array}{c}\text { LFG } \\
\text { Normal }\end{array}$} & \multicolumn{2}{c}{ Menurun } & \multirow{P}{*}{} \\
\cline { 2 - 5 } & $\mathbf{n}$ & $\mathbf{\%}$ & $\mathbf{n}$ & $\mathbf{\%}$ & \\
\hline Optimal & 4 & 2 & 27 & 13,1 & 0,088 \\
Meningkat & 8 & 4 & 166 & 80,9 & $(p>0,05)$ \\
Total & 12 & 6 & 193 & 94 & \\
\hline
\end{tabular}


Dari hasil penelitian menunjukan bahwa terdapat 10 orang (4,6\%) dengan tidak ada DM memiliki LFG normal dan terdapat 2 orang (1\%) memiliki LFG menurun, sedangkan pada pasien dengan ada riwayat DM terdapat 2 orang (1\%) dengan LFG normal dan terdapat 50 orang (24,4\%) dengan LFG menurun. Nilai $p=0,333$ berarti dalam penelitian ini tidak terdapat hubungan yang signifikan antara variabel DM dengan LFG (Tabel 4).

Tabel 4. Distribusi berdasarkan riwayat DM dan LFG

\begin{tabular}{|c|c|c|c|c|c|}
\hline \multirow{2}{*}{$\begin{array}{c}\text { Riwayat } \\
\text { DM }\end{array}$} & \multicolumn{2}{|c|}{$\begin{array}{c}\text { LFG } \\
\text { Normal }\end{array}$} & \multicolumn{2}{|c|}{ LFG Menurun } & \multirow{2}{*}{$P$} \\
\hline & $\mathrm{n}$ & $\%$ & $\mathrm{n}$ & $\%$ & \\
\hline Tidak DM & 10 & 4,6 & 143 & 70 & 0,333 \\
\hline DM & 2 & 1 & 50 & 24,4 & $(p>0,05)$ \\
\hline Total & 12 & 5,8 & 193 & 94,4 & \\
\hline
\end{tabular}

Dari hasil penelitian menunjukan bahwa terdapat 7 orang $(3,4 \%)$ dengan tidak mempunyai riwayat merokok memiliki LFG normal dan terdapat 152 orang (74,1\%) memiliki LFG menurun, sedangkan pada pasien dengan riwayat merokok terdapat 5 orang (2,5\%) dengan LFG normal dan terdapat 41 orang (20\%) dengan LFG menurun. Nilai $p=0,103$ berarti dalam penelitian ini tidak bisa dibuktikan adanya hubungan yang signifikan antara variabel umur dengan LFG (Tabel 5).

Tabel 5. Distribusi berdasarkan riwayat merokok dan LFG

\begin{tabular}{cccccc}
\hline \multirow{2}{*}{$\begin{array}{c}\text { Riwayat } \\
\text { Merokok }\end{array}$} & \multicolumn{2}{c}{ LFG } & \multicolumn{2}{c}{ LFG } & \multirow{2}{*}{ Normal } \\
\cline { 2 - 5 } & $\mathbf{n}$ & $\mathbf{\%}$ & $\mathbf{n}$ & $\mathbf{\%}$ & \\
\hline Tidak & 7 & 3,4 & 152 & 74,1 & 0,103 \\
Merokok & & & & \\
Merokok & 5 & 2,5 & 41 & 20 & $(p>0,05)$ \\
Total & 12 & 5,9 & 193 & 94,1 & \\
\hline
\end{tabular}

\section{BAHASAN}

Penyakit Jantung Koroner (PJK) merupakan kondisi yang terjadi akibat penumpukan plak di arteri jantung sehingga mengakibatkan suplai darah ke jantung menjadi terganggu dan bisa menyebabkan serangan jantung. ${ }^{1}$ Old Myocardial Infarction (OMI) merupakan salah satu dari $\mathrm{PJK}^{7}$ yang akan dibahas dalam penelitian ini. Berikut akan diuraikan hasil faktor risiko PJK yang dapat meningkatkan prevalensi OMI dan hubungannya dengan laju filtrasi glomerulus (LFG):

Hasil penelitian di poli jantung Prof. Dr. R. D. Kandou Manado selama selang waktu Januari 2013 - Desember 2013 mendapatkan bahwa terdapat hubungan antara usia lanjut dengan LFG yang menurun pada pasien OMI $(p=0,000)$. Hal ini sesuai dengan sumber kepustakaan yang menyatakan bahwa setelah usia 40 tahun, jumlah nefron umumnya akan berkurang 10 \% setiap 10 tahun sehingga pada usia 80 tahun jumlah nefron menjadi $40 \%$ lebih sedikit dari pada ketika usia 40 tahun $^{2}$. Penelitian Fenty juga menyatakan bahwa terdapat hubungan yang bermakna antara usia lanjut dengan penurunan LFG $(p=0,000){ }^{8}$

Hasil penelitian di poli jantung Prof. Dr. R. D. Kandou Manado selama selang waktu Januari 2013 - Desember 2013 mendapatkan bahwa terdapat hubungan antara hipertensi dengan LFG yang menurun pada pasien OMI $(p=0,048)$. Hal in sesuai dengan sumber kepustakaan bahwa penderita hipertensi tidak hanya beresiko menderita penyakit jantung, tetapi juga menderita penyakit lain seperti saraf, ginjal, dan pembuluh darah. Makin tinggi tekanan darah, makin tinggi risikonya. ${ }^{9}$

Kerusakan pembuluh darah akibat hipertensi terlihat jelas di seluruh pembuluh darah perifer. Bila pembuluh darah menyempit maka aliran arteri terganggu dan dapat menyebabkan mikro infark jaringan. Akibat perubahan pembuluh darah ini paling nyata terjadi pada otak dan ginjal. ${ }^{10}$ Penyumbatan arteria dan arteriol akan menyebabkan kerusakan glomerulus dan atrofi tubulus, sehingga seluruh nefron rusak. $^{9}$ 
Studi Lisna Unita dan Harun Rasyid Lubis melaporkan secara statistik bahwa ada hubungan yang bermakna antara profil lipid LDL dengan CKD $(p=0,002) .{ }^{11}$ Terjadinya hiperlipidemia pada penderita CKD merupakan salah satu faktor risiko PJK yang adalah penyebab utama kematian dimana insidennya kurang lebih 40-50\%. ${ }^{11}$ Hasil yang didapatkan pada penelitian ini bahwa tidak terdapat hubungan antara kadar kolestrol LDL yang meningkat dengan penurunan LFG pada pasien OMI $(p=0,088)$. Hal ini dapat disebabkan karena penggunaan terapi obat antilipidemik pada pasien OMI sehingga dapat mempengaruhi kadar kolestrol LDL. Keterbatasan penelitian ini adalah pemberian obat antilipidemik pada pasien OMI dan riwayat hiperlipidemia tidak ditelusuri.

Kelebihan atau banyaknya protein yang dikonsumsi menyebabkan metabolisme yang berlebihan di glomerulus ginjal. Tentu saja bila hal itu dibiarkan cukup lama akan menyebabkan kelelahan dan kerusakan pada glomerulus dan bukan tak mungkin menyababkan LFG turun. ${ }^{12}$

Penelitian Linda Febryana menyatakan secara statistik bahwa tidak terdapat hubungan antara DM dan LFG yang menurun $(p=0,57) .{ }^{13}$ Penelitian crossectional dari Australia juga menemukan bahwa DM berhubungan dengan proteinuria, tetapi tidak menurunkan LFG. ${ }^{13}$ Berdasarkan hasil penelitian yang dilakukan penulis menunjukan bahwa tidak terdapat hubungan antara adanya riwayat DM dengan penurunan LFG pada pasien OMI $(p=0,333)$. Hal ini dapat terjadi karena sampel OMI yang terdapat riwayat DM hanya sedikit dan keterbatasan penulis menulusuri riwayat DM dengan pemakaian obat anti diabetes (OAD) pada pasien OMI.

Merokok dapat menyebabkan terjadinya thrombosis sengan cara memproduksi stress oksidatif, disfungsi endotel dan aktivasi platelet, yang juga dalam waktu lama akan menyebabkan aterosklerosis dan trombosis, yang juga akan menyebabkan kerusakan sensifitas insulin dan disfungsi ginjal. ${ }^{10}$
Pada penelitian ini tidak didapatkan hubungan antara merokok dengan penurunan LFG pada pasien OMI $(p=0,103)$. Hal ini dapat terjadi karena data yang diperoleh hanya berdasarkan riwayat merokok pasien tanpa mengetahui jumlah dan lamanya pasien merokok.

\section{SIMPULAN DAN SARAN}

Terdapat hubungan yang signifikan antara usia dan riwayat hipertensi dengan LFG pada pasien OMI. Tidak terdapat hubungan yang signifikan antara hiperlipidemia, riwayat DM dan riwayat merokok dengan LFG pada pasien OMI.

Pasien diharapkan dapat mengenali gejala dari PJK, sehingga bisa mendapatkan pengobatan secepatnya. Perlu adanya pengetahuan tentang kontrol faktor-faktor risiko PJK pada pasien OMI untuk mengendalikan komplikasi lebih lanjut termasuk disfungsi ginjal. Perlu adanya penelitian lanjut tentang faktor-faktor risiko PJK yang dapat mempengaruhi LFG sehingga penelitian ini bisa disempurnakan. Penyimpanan rekam medik oleh bagian rekam medik agar bisa diatur secara rapi agar memudahkan pencarian data untuk penelitian-penelitian selanjutnya.

\section{DAFTAR PUSTAKA}

1. American Heart Association. Coronary Artery Disease: Coronary Heart Disease. 2013.

Available

from: http://www.heart.org/HEARTORG/C onditions/More/MyHeartandStrokeNews/Co ronary-Artery-Disease---The-ABCs-ofCAD_UCM_436416_Article.jsp

2. Kasron, Ns. Kelainan dan Penyakit Jantung Pencegahan Serta Pengobatannya.

Yogyakarta; Nuha Medika, 2012

3. Burns D, Kumar V. Jantung Dalam: Kumar V, Cotran R, Robbins S, Buku Ajar Patologi volume 2 edisi 7. Jakarta; EGC, 2007

4. Melati, Rima, Endang Basuki, Budhi Setianto. Relationship Between Job Strain and Myocardial Infarction in The National Cardiovascular Center Patient. Jurnal Kedokteran Indonesia; 2008. 29: 12-19 
5. Asvin Nurulita, Uleng Bahrun, Mansyur Arif. Perbandingan Kadar Apolipoprotein dan Fraksi Lipid Sebagai Faktor Resiko Penyakit Jantung Koroner. JST Kesehatan; 2011. 1: 94-100

6. Arthur C. Guyton, John E. Hall. Pembentukan Urin oleh Ginjal: I. Filtrasi Glomerulus, Aliran Darah Ginjal, dan Pengaturannya. Dalam: Buku Ajar Fisiologi Kedokteran edisi 11. Jakarta: EGC, 2008

7. Garibyan, Lilit. Lily, Leonard S. Pathophysiology of Heart Disease : The Electrocardiogram. 2006. Page 102

8. Fenty. Laju Filtrasi Glomerulus pada Lansia Berdasarkan Tes Klirens Kreatinin dengan Formula Cockroft Gault, Cockroft Gault Standarisasi, dan MDRD. Jurnal Penelitian Vol 13; 2010
9. Lorraine M, Wilson. Gagal Ginjal Kronik. Dalam Patofisiologi Konsep-Konsep Klinis Penyakit. Jakarta; EGC, 2005

10. Gray H. H., Dawkins K.D., Simpson I.A., Morgan J.M. Lecture Notes: Kardiologi. Jakarta: Erlangga, 2005

11. Lisna Unita, Harun Rasyid. Profil Lipid Penderita Penyakit Ginjal Kronis pada Predialisis dan Hemodialisis. Majalah Kedokteran Nusantara Vol. 38, No. 2; 2005

12. Young, James. Libby, Peter. Pathophysiology of Heart Disease: Atherosclerosis. 2006. Page 118

13. Linda Febryana, Dwi Pangastuty. Hipertensi, Obesitas Sentral dan Diabetes Mellitus Sebagai Prediktor Kejadian Penyakit Ginjal Kronik. Program Pascasarjana. Universitas Udayana. Denpasar; 2012. 